\title{
Administration of hydrogen sulfide via extracorporeal membrane lung ventilation in sheep with partial cardiopulmonary bypass perfusion: a proof of concept study on metabolic and vasomotor effects
}

Matthias Derwall ${ }^{1,2^{*}}$, Roland CE Francis ${ }^{1 \dagger}$, Kotaro Kida ${ }^{1}$, Masahiko Bougaki ${ }^{1}$, Ettore Crimi ${ }^{1}$, Christophe Adrie ${ }^{1}$, Warren M Zapol ${ }^{1}$, Fumito Ichinose ${ }^{1}$

\begin{abstract}
Introduction: Although inhalation of 80 parts per million (ppm) of hydrogen sulfide $\left(\mathrm{H}_{2} \mathrm{~S}\right)$ reduces metabolism in mice, doses higher than $200 \mathrm{ppm}$ of $\mathrm{H}_{2} \mathrm{~S}$ were required to depress metabolism in rats. We therefore hypothesized that higher concentrations of $\mathrm{H}_{2} \mathrm{~S}$ are required to reduce metabolism in larger mammals and humans. To avoid the potential pulmonary toxicity of $\mathrm{H}_{2} \mathrm{~S}$ inhalation at high concentrations, we investigated whether administering $\mathrm{H}_{2} \mathrm{~S}$ via ventilation of an extracorporeal membrane lung (ECML) would provide means to manipulate the metabolic rate in sheep.

Methods: A partial venoarterial cardiopulmonary bypass was established in anesthetized, ventilated (fraction of inspired oxygen $=0.5$ ) sheep. The ECML was alternately ventilated with air or air containing 100,200 , or 300 ppm $\mathrm{H}_{2} \mathrm{~S}$ for intervals of 1 hour. Metabolic rate was estimated on the basis of total $\mathrm{CO}_{2}$ production $\left(\dot{\mathrm{V}} \mathrm{CO}_{2}\right.$ ) and $\mathrm{O}_{2}$ consumption $\left(\dot{\mathrm{V}}_{2}\right)$. Continuous hemodynamic monitoring was performed via indwelling femoral and pulmonary artery catheters.

Results: $\dot{\mathrm{V}} \mathrm{CO}_{2}, \dot{\mathrm{V}} \mathrm{O}_{2}$, and cardiac output ranged within normal physiological limits when the ECML was ventilated with air and did not change after administration of up to $300 \mathrm{ppm} \mathrm{H}_{2} \mathrm{~S}$. Administration of 100, 200 and $300 \mathrm{ppm} \mathrm{H}_{2} \mathrm{~S}$ increased pulmonary vascular resistance by 46,52 and 141 dyn.5/ $\mathrm{cm}^{5}$, respectively (all $P \leq 0.05$ for air vs. 100, 200 and 300 ppm H $\mathrm{H}_{2}$ S, respectively), and mean pulmonary artery pressure by $4 \mathrm{mmHg}(P \leq 0.05), 3 \mathrm{mmHg}$ (n.s.) and $11 \mathrm{mmHg}(P \leq 0.05)$, respectively, without changing pulmonary capillary wedge pressure or cardiac output. Exposure to $300 \mathrm{ppm} \mathrm{H}_{2} \mathrm{~S}$ decreased systemic vascular resistance from 1,561 \pm 553 to $870 \pm 138 \mathrm{dyn} \cdot \mathrm{s} / \mathrm{cm}^{5}$ $(P \leq 0.05)$ and mean arterial pressure from $121 \pm 15 \mathrm{mmHg}$ to $66 \pm 11 \mathrm{mmHg}(P \leq 0.05)$. In addition, exposure to 300 ppm $\mathrm{H}_{2} \mathrm{~S}$ impaired arterial oxygenation $\left(\mathrm{P}_{\mathrm{a}} \mathrm{O}_{2} 114 \pm 36 \mathrm{mmHg}\right.$ with air vs. $83 \pm 23 \mathrm{mmHg}$ with $\left.\mathrm{H}_{2} \mathrm{~S} ; P \leq 0.05\right)$.

Conclusions: Administration of up to $300 \mathrm{ppm} \mathrm{H}_{2} \mathrm{~S}$ via ventilation of an extracorporeal membrane lung does not reduce $\dot{\mathrm{V}} \mathrm{CO}_{2}$ and $\dot{\mathrm{V}}_{2}$, but causes dose-dependent pulmonary vasoconstriction and systemic vasodilation. These results suggest that administration of high concentrations of $\mathrm{H}_{2} \mathrm{~S}$ in venoarterial cardiopulmonary bypass circulation does not reduce metabolism in anesthetized sheep but confers systemic and pulmonary vasomotor effects.
\end{abstract}

\footnotetext{
* Correspondence: mderwall@partners.org

† Contributed equally

'Anesthesia Center for Critical Care Research, Department of Anesthesia,

Critical Care and Pain Medicine, Massachusetts General Hospital and Harvard

Medical School, 55 Fruit Street, Boston, MA 02114, USA

Full list of author information is available at the end of the article
} 


\section{Introduction}

Balancing cellular oxygen supply and demand is a key therapeutic approach to protecting organs such as the brain, kidneys and heart from ischemic injury. Permissive hypothermia and active cooling have been shown to reduce oxygen demands in patients experiencing stroke, cardiac arrest, cardiac surgery, severe trauma and other instances of ischemia and subsequent reperfusion [1-4]. However, hypothermic reduction of aerobic metabolism has been associated with adverse effects, including increased rates of infection and coagulopathy $[5,6]$. Developing other methods to acutely reduce metabolism in patients could be clinically useful.

Hydrogen sulfide $\left(\mathrm{H}_{2} \mathrm{~S}\right)$ is an inhibitor of cytochrome $\mathrm{C}$ oxidase in the mitochondrial electron transport chain [7] that reduces metabolism and body temperature in mice and rats $[8,9]$. Inhalation of $\mathrm{H}_{2} \mathrm{~S}$ or intravenous administration of $\mathrm{H}_{2} \mathrm{~S}$ donor compounds $(\mathrm{NaHS}$ or $\mathrm{Na}_{2} \mathrm{~S}$ ) can protect rodents from hypoxia [10] or hemorrhagic shock [11], improve survival rates after cardiac arrest and cardiopulmonary resuscitation in mice [12], and attenuate myocardial ischemia-reperfusion injury in both rodents [13] and pigs [14].

Although inhaling $\mathrm{H}_{2} \mathrm{~S}$ at 60 to $80 \mathrm{ppm}$ reduces metabolism in mice, it has been reported that inhaled $\mathrm{H}_{2} \mathrm{~S}$ does not depress total $\mathrm{CO}_{2}$ production $\left(\dot{\mathrm{V}}_{2} \mathrm{CO}_{2}\right)$ and total $\mathrm{O}_{2}$ consumption $\left(\dot{\mathrm{VO}}_{2}\right)$ in sedated, spontaneously breathing sheep $\left(60 \mathrm{ppm} \mathrm{H}_{2} \mathrm{~S}\right)$ [15] or anesthetized, ventilated piglets (20 to $80 \mathrm{ppm}_{2} \mathrm{~S}$ ) [16]. On the other hand, Struve et al. [8] reported that inhalation of $\mathrm{H}_{2} \mathrm{~S}$ at 200 to $400 \mathrm{ppm}$, but not at 30 to $80 \mathrm{ppm}$, decreased body temperature in rats. Similarly, Morrison et al. [11] showed that inhaling $\mathrm{H}_{2} \mathrm{~S}$ at $300 \mathrm{ppm}$ was required to decrease $\mathrm{VCO}_{2}$ in rats, in contrast to $80 \mathrm{ppm}$ in mice. While these observations suggest that higher levels of $\mathrm{H}_{2} \mathrm{~S}$ are likely to be required to alter metabolic rates in larger animals [11], the effects of higher concentrations of $\mathrm{H}_{2} \mathrm{~S}$ on metabolism in larger mammals have not been examined.

It is well documented, however, that inhalation of high concentrations of $\mathrm{H}_{2} \mathrm{~S}$ may injure the bronchial mucosa, cause pulmonary edema, and impair gas exchange $[17,18]$. To examine the impact of delivering higher concentrations of $\mathrm{H}_{2} \mathrm{~S}$ to the body without incurring the pulmonary toxicity of $\mathrm{H}_{2} \mathrm{~S}$ inhalation, we administered $\mathrm{H}_{2} \mathrm{~S}$ gas via an extracorporeal membrane lung (ECML). We hypothesized that high concentrations of $\mathrm{H}_{2} \mathrm{~S}$ delivered via ECML in a partial venoarterial bypass system delivering blood to the aortic root might reduce the metabolic rate in sheep at rest. If ECML ventilation with $\mathrm{H}_{2} \mathrm{~S}$ was found to reduce the metabolic rate in sheep, this method might provide a novel approach to balance the supply and demand of oxygen in a variety of situations, including in those patients who are supported by extracorporeal circulation during cardiac surgery or severe acute respiratory distress.

\section{Materials and methods}

All procedures described here were approved by the Subcommittee on Research Animal Care of the Massachusetts General Hospital, Boston, MA, USA, and adhered to the principles of the Declaration of Helsinki and the Recommendations for the Care and Use of Animals.

\section{Animal housing and maintenance}

Five female purebred Polypay sheep (body weight: 30.6 $\pm 2.5 \mathrm{~kg}$, mean $\pm \mathrm{SD}$ ) were obtained from a singlesource breeder (New England Ovis LLC, Rollinsford, $\mathrm{NH}, \mathrm{USA}$ ) and were housed under standard environmental conditions (air-conditioned room at $22^{\circ} \mathrm{C}, 50 \%$ relative humidity, 12-hour light-dark cycle) for at least 5 days prior to each study. Animals were fed standard chow (Rumilab diet 5508; PMI Feeds Inc., St. Louis, MO, USA) twice daily and were fasted for 24 hours with free access to water before each experiment.

\section{Instrumentation}

After intramuscular premedication with $5 \mathrm{mg} / \mathrm{kg}$ ketamine (ketamine hydrochloride; Hospira Inc., Lake Forest, IL, USA) and $0.1 \mathrm{mg} / \mathrm{kg}$ xylazine (Anased; Lloyd Laboratories, Shenandoah, IA, USA), a venous cannula (Surflo IV catheter 18G; Terumo, Elkton, MD, USA) was inserted into an ear vein and a bolus of 0.1 to 0.2 $\mathrm{mg} / \mathrm{kg}$ diazepam (Diazepam USP; Hospira, Lake Forest, IL, USA) administered intravenously (iv). Subsequently, the animals were placed in a supine position and were intubated and mechanically ventilated with a volumecontrolled mode (fraction of inspired oxygen $\left(\mathrm{F}_{\mathrm{i}} \mathrm{O}_{2}\right)$ $50 \%$, tidal volume $10 \mathrm{ml} / \mathrm{kg}$ ) (7200 Series Ventilator System; Puritan Bennett, Boulder, CO, USA). Anesthesia was maintained by a constant rate infusion of ketamine at $3 \mathrm{mg} \cdot \mathrm{kg}^{-1} \cdot \mathrm{h}^{-1}$ and diazepam at $0.5 \mathrm{mg} \cdot \mathrm{kg}^{-1} \cdot \mathrm{h}^{-1}$. Respiratory rate was adjusted to maintain the end-tidal $\mathrm{CO}_{2}$ between 35 and $40 \mathrm{mmHg}$. An arterial catheter (18G, FA-04018; Arrow Inc., Reading, PA, USA) was placed into the right femoral artery via percutaneous puncture to monitor mean arterial pressure (MAP) and to sample blood. Subsequently, an 8-Fr heptalumen pulmonary artery catheter (746HF8; Edwards Lifesciences, Irvine, CA, USA) was introduced through a percutaneous sheath (9 Fr, PB-09903; Arrow Inc., Reading, PA, USA) into the left external jugular vein for blood sampling and monitoring of mean pulmonary artery pressure (MPAP), central venous pressure (CVP), pulmonary capillary wedge pressure (PCWP), continuous cardiac 
output $(\mathrm{CO})$ and blood temperature. Finally, a transurethral bladder catheter and a transesophageal gastric tube were inserted to drain urine and gastric secretions. During the first hour after induction, animals received an infusion of $500 \mathrm{ml}$ of 6\% hetastarch (Hextend; Hospira, Lake Forest, IL, USA) and $500 \mathrm{ml}$ of lactated Ringer's solution (Baxter, Deerfield, IL, USA); thereafter, 16 $\mathrm{ml} \cdot \mathrm{kg}^{-1} \cdot \mathrm{h}^{-1}$ of lactated Ringer's solution and $9 \mathrm{ml} \cdot \mathrm{kg}^{-1} \cdot \mathrm{h}^{-1}$ of $0.9 \%$ saline were infused to match fluid losses from diuresis and gastric secretions.

\section{Extracorporeal circulation}

A 20-Fr single-stage venous cannula (DLP; Medtronic, Minneapolis, MN, USA) and a 14-Fr arterial cannula (Fem-Flex II; Medtronic) were surgically inserted and advanced through the right external jugular vein and right common carotid artery, respectively, thereby enabling blood withdrawal from the superior vena cava and arterial blood return to the aortic root from the extracorporeal cardiopulmonary bypass circuit. The bypass circuit comprised a three-eighths-inch polyethylene tubing line (3506; Medtronic), an occlusive roller pump (Cardiovascular Instruments Corp., Wakefield, MA, USA) and an ECML (Trillium 541TT Affinity; Medtronic) with an integral heat exchanger, and it was primed with a total extracorporeal priming volume of $500 \mathrm{ml}$ of $0.9 \%$ saline. A bolus injection of unfractionated heparin (200 IU/kg heparin sodium; APP Pharmaceuticals, LLC, Schaumburg, IL, USA) prior to cannulation, followed by a continuous infusion of 200 $\mathrm{IU} / \mathrm{kg}$ unfractionated heparin per hour was used for anticoagulation. A thermostat-controlled water bath (Haake DC10-P5; Thermo Scientific, Waltham, MA, USA) supplying the heat exchanger with circulating water was maintained at $38^{\circ} \mathrm{C}$. The gas compartment of the oxygenator was ventilated at a constant flow of $5 \mathrm{l} /$ min with oxygen, air and $\mathrm{H}_{2} \mathrm{~S}(10,000$ ppm hydrogen sulfide balanced with nitrogen; Airgas Specialty Gases, Port Allen, LA, USA) blended to achieve an oxygen concentration of $21 \%$ with $0,100,200$, or $300 \mathrm{ppm} \mathrm{H}_{2} \mathrm{~S}$.

A handheld iTX Multi-Gas detector (1 ppm detection threshold; Industrial Scientific, Oakdale, PA, USA) was used to monitor the $\mathrm{H}_{2} \mathrm{~S}$ concentrations at the inlet and outlet of the gas compartment.

\section{Experimental procedures}

Once partial venoarterial bypass perfusion was started, the transmembrane blood flow was gradually increased to $1 \mathrm{l} / \mathrm{min}$. Then the respiratory rate was reduced to maintain an end-tidal partial pressure of $\mathrm{CO}_{2}$ of 35 to $40 \mathrm{mmHg}$, and sheep were paralyzed $\left(0.1 \mathrm{mg} \cdot \mathrm{kg}^{-1} \cdot \mathrm{h}^{-1}\right.$ of pancuronium bromide iv; Sicor Pharmaceuticals, Irvine, CA, USA) to prevent spontaneous respiratory activity, asynchronous ventilation and excessive skeletal muscle
$\mathrm{O}_{2}$ consumption. A 1-hour equilibration period was allowed to achieve hemodynamic stability before baseline measurements were taken.

During the following 6 hours, the ECML gas compartment was alternately ventilated with either air or air plus $\mathrm{H}_{2} \mathrm{~S}$ for 1-hour intervals, thereby administering $0 \mathrm{ppm} \mathrm{H}_{2} \mathrm{~S}$ during the first hour, $100 \mathrm{ppm}_{2} \mathrm{~S}$ during the second hour, followed by 0 and $200 \mathrm{ppm}$ during the third and fourth hours and finally 0 and 300 ppm $\mathrm{H}_{2} \mathrm{~S}$ during the fifth and sixth hours. This procedure was chosen to detect the hemodynamic and metabolic effects of exposure to increasing $\mathrm{H}_{2} \mathrm{~S}$ concentrations through the membrane lung, as well as their reversibility.

\section{Measurements and monitoring}

A digital data acquisition system (PowerLab and Chart software version 5.0; ADInstruments, Colorado Springs, CO, USA) was used to continuously record MAP, CVP and MPAP. A Vigilance II Monitor (Edwards Lifesciences) was used to continuously measure $\mathrm{CO}$ and central blood temperature. End-tidal $\mathrm{CO}_{2}$, as well as the total amount of $\mathrm{CO}_{2}$ exhaled from the biological lungs per unit of time $\left(\dot{\mathrm{V}}_{\mathrm{L}} \mathrm{CO}_{2}\right)$, was measured by an instream, noninvasive, continuous monitoring device (NICO Cardiopulmonary Management System; Philips Respironics, Murrysville, PA, USA). Blood gas tensions, hemoglobin concentrations, and acid-base balances were determined in arterial and mixed venous blood samples using a standard blood gas analyzer (ABL 800 Flex; Radiometer, Copenhagen, Denmark).

Plasma concentrations of $\mathrm{H}_{2} \mathrm{~S}$ were measured in duplicate as total sulfide concentrations using the methylene blue formation method with modifications [19]. Briefly, arterial and ECML-efferent blood was sampled and immediately centrifuged at $4^{\circ} \mathrm{C}$ to obtain plasma. An aliquot of plasma $(100 \mu \mathrm{l})$ was added with $2 \%$ zinc acetate $(200 \mu \mathrm{l})$ to trap the $\mathrm{H}_{2} \mathrm{~S}$, and $10 \%$ trichloroacetic acid $(200 \mu \mathrm{l})$ was added to precipitate plasma proteins,

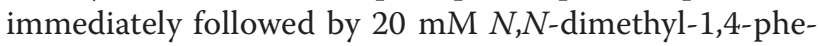
nylenediamine sulfate in $7.2 \mathrm{M} \mathrm{HCl}(100 \mu \mathrm{l})$ and 30 $\mathrm{mM} \mathrm{FeCl}_{3}$ in $1.2 \mathrm{M} \mathrm{HCl}(100 \mu \mathrm{l})$. The reaction mixture was incubated for 20 minutes at room temperature and centrifuged at $14,000 \mathrm{rpm}$ for 10 minutes. The absorbance of the supernatant was measured at $670 \mathrm{~nm}$ using a spectrophotometer. Total sulfide concentration was calculated against a standard curve made with known concentrations of $\mathrm{Na}_{2} \mathrm{~S}$ solutions in phosphate-buffered saline. The lower detection limit of this assay was approximately $1 \mu \mathrm{M}$ sulfide in plasma.

\section{Calculation of carbon dioxide production}

Total $\dot{\mathrm{VCO}}_{2}$ was monitored continuously and was calculated as the sum of $\mathrm{CO}_{2}$ exhaled from the lungs per unit of time $\left(\dot{\mathrm{V}}_{\mathrm{L}} \mathrm{CO}_{2}\right)$ and the amount of $\mathrm{CO}_{2}$ 
removed from the circulation via the membrane oxygenator $\left(\dot{\mathrm{V}}_{\mathrm{M}} \mathrm{CO}_{2}\right)$, according to the following equations:

$$
\dot{\mathrm{V}}_{\mathrm{L}} \mathrm{CO}_{2}=\dot{\mathrm{V}}_{\mathrm{E}} \times F_{\mathrm{E}} \mathrm{CO}_{2} \text {, }
$$

where $\dot{V}_{\mathrm{E}}$ is the expiratory minute volume and $F_{\mathrm{E}} \mathrm{CO}_{2}$ is the mean fraction of $\mathrm{CO}_{2}$ in expired air. Quantification of $\dot{\mathrm{V}}_{\mathrm{E}}$ and $F_{\mathrm{E}} \mathrm{CO}_{2}$ and the calculation of $\dot{\mathrm{V}}_{\mathrm{L}} \mathrm{CO}_{2}$ were accomplished by a continuous noninvasive NICO device (see 'Measurements and monitoring' section):

$$
\dot{\mathrm{V}}_{\mathrm{M}} \mathrm{CO}_{2}=\mathrm{Q}_{\text {gas }} \times \mathrm{F}_{\mathrm{M}} \mathrm{CO}_{2},
$$

where $\mathrm{Q}_{\text {gas }}$ is the total gas flow exhausted from the membrane oxygenator and $F_{\mathrm{E}} \mathrm{CO}_{2}$ is the fraction of $\mathrm{CO}_{2}$ in the exhaust gas. $\mathrm{Q}_{\text {gas }}$ was continuously monitored by a microturbine flow meter (S-113 Flo-Meter; McMillan Co., Georgetown, TX, USA), and $F_{\mathrm{E}} \mathrm{CO}_{2}$ was measured by a sidestream infrared $\mathrm{CO}_{2}$ analyzer (WMA-4; PP-Systems, Amesbury, MA, USA).

\section{Calculation of oxygen consumption}

Total $\mathrm{VO}_{2}$ was calculated on the basis of blood samples drawn 10 minutes before the end of each period of exposure to air or $\mathrm{H}_{2} \mathrm{~S}$ as follows:

$$
\dot{\mathrm{V}} \mathrm{O}_{2}=\left(\mathrm{c}_{\mathrm{a}} \mathrm{O}_{2}-\mathrm{c}_{\mathrm{v}} \mathrm{O}_{2}\right) \times \mathrm{Q}_{\mathrm{L}}-\left(\mathrm{c}_{\mathrm{e}} \mathrm{O}_{2}-\mathrm{c}_{\mathrm{a}} \mathrm{O}_{2}\right) \times \mathrm{Q}_{\mathrm{M}},
$$

where $\mathrm{c}_{\mathrm{a}} \mathrm{O}_{2}$ is the oxygen content of arterial blood, $\mathrm{C}_{\mathrm{v}} \mathrm{O}_{2}$ is the oxygen content of mixed venous blood, $\mathrm{Q}_{\mathrm{L}}$ is transpulmonary blood flow (here meaning continuous $\mathrm{CO}$ measured via pulmonary artery catheter), $\mathrm{c}_{\mathrm{e}} \mathrm{O}_{2}$ is the oxygen content of ECML-efferent blood and $\mathrm{Q}_{M}$ is extrapulmonary blood flow (here meaning transmembrane blood flow). Blood oxygen content $\left(\mathrm{cO}_{2}\right)$ was calculated according to the following general equation:

$$
\mathrm{cO}_{2}=[\mathrm{Hb}] \times \mathrm{FO}_{2} \mathrm{Hb} \times 1.34+\mathrm{pO}_{2} \times 0.003,
$$

where $[\mathrm{Hb}]$ is the hemoglobin concentration, $\mathrm{FO}_{2} \mathrm{Hb}$ is the fraction of oxyhemoglobin, 1.34 is Hüfner's constant and $\mathrm{pO}_{2}$ is the oxygen tension.

\section{Statistical analysis}

Statistical analysis was performed using the SPSS 14.0 data package for Windows (SPSS, Chicago, IL, USA) and GraphPad Prism version 5.02 software (GraphPad Software, La Jolla, CA, USA). All data are reported as means \pm SD unless indicated otherwise. Hemodynamic parameters, $\mathrm{V} \mathrm{CO}_{2}$ and body temperature were measured continuously and are reported as the mean value derived from the last 10 minutes of each period of exposure to air or $\mathrm{H}_{2} \mathrm{~S}$. In addition, hemodynamic parameters were averaged every 5 minutes for a time course analysis, and these data are displayed in Figures 1 and 2 . Blood gas tension analysis, determination of blood hemoglobin concentrations and quantification of $\mathrm{H}_{2} \mathrm{~S}$ plasma concentrations required blood sampling. Samples were obtained during the last 5 minutes of each period of exposure. Depending on the distribution of the data as determined using the Shapiro-Wilk test for normal distribution, either Student's $t$-test or the Wilcoxon signed-rank test was performed to compare each $\mathrm{H}_{2} \mathrm{~S}$ ventilation period with the respective baseline period $(0$ ppm $\mathrm{H}_{2} \mathrm{~S}$ ). Statistical significance was assumed at $P \leq$ 0.05 . On the basis of data derived from pilot experiments, power and sample size calculations were performed using PS: Power and Sample Size Calculation version 2.1.31 software by Dupont and Plummer [20].

\section{Results}

\section{Metabolic effects of $\mathrm{H}_{2} \mathrm{~S}$ administration}

The baseline $\dot{\mathrm{V}} \mathrm{CO}_{2}$ value was stably near approximately $3.4 \mathrm{ml} \cdot \mathrm{kg}^{-1} \cdot \mathrm{min}^{-1}$ when the ECML was ventilated with air. Direct diffusion of $\mathrm{H}_{2} \mathrm{~S}$ into blood via the ECML at 100,200 or $300 \mathrm{ppm}$ did not alter $\dot{\mathrm{V}} \mathrm{CO}_{2}$ (Figure 3 ) or $\dot{\mathrm{VO}}_{2}$ (Figure 4). The temperature of the ECML heat exchanger water bath was kept at $38^{\circ} \mathrm{C}$ and resulted in a constant central blood temperature of $37.4 \pm 0.4^{\circ} \mathrm{C}$ throughout the experiment (Table 1).

\section{Hemodynamic effects of $\mathrm{H}_{2} \mathrm{~S}$ administration}

After 1 hour of exposure to either 100 or 200 ppm $\mathrm{H}_{2} \mathrm{~S}$ via ECML ventilation and partial venoarterial perfusion, MAP was not different from baseline. However, exposure to $300 \mathrm{ppm}_{2} \mathrm{~S}$ for 1 hour decreased MAP from $121 \pm 15 \mathrm{mmHg}$ to $66 \pm 11 \mathrm{mmHg}$ and reduced

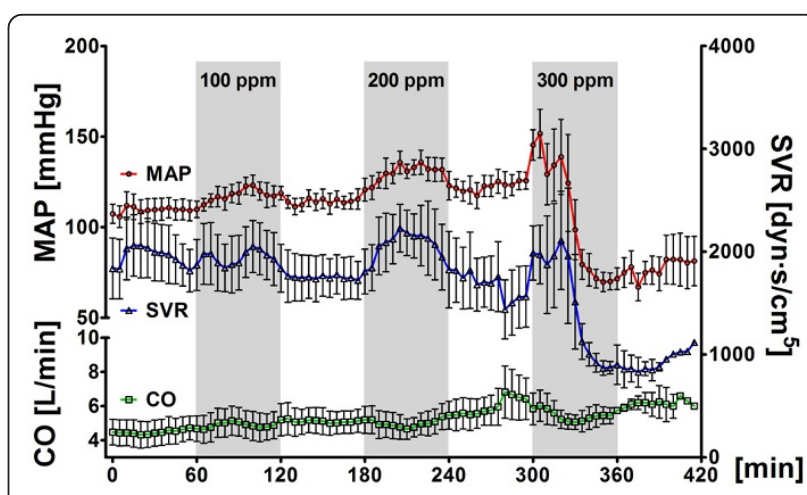

Figure 1 Systemic vascular hemodynamics. Systemic vascular hemodynamics in five sheep challenged with alternate exposure to hydrogen sulfide $\left(\mathrm{H}_{2} \mathrm{~S}\right)$ (gray bars) by ventilation of an extracorporeal membrane lung with 0 or 100 ppm $\mathrm{H}_{2} \mathrm{~S}$ in air, 200 ppm $\mathrm{H}_{2} \mathrm{~S}$ in air and 300 ppm $\mathrm{H}_{2} \mathrm{~S}$ in air for 1-hour intervals each. Data are presented as means \pm standard error of the mean. MAP, mean arterial pressure; CO, cardiac output; SVR, systemic vascular resistance; ppm, parts per million. 


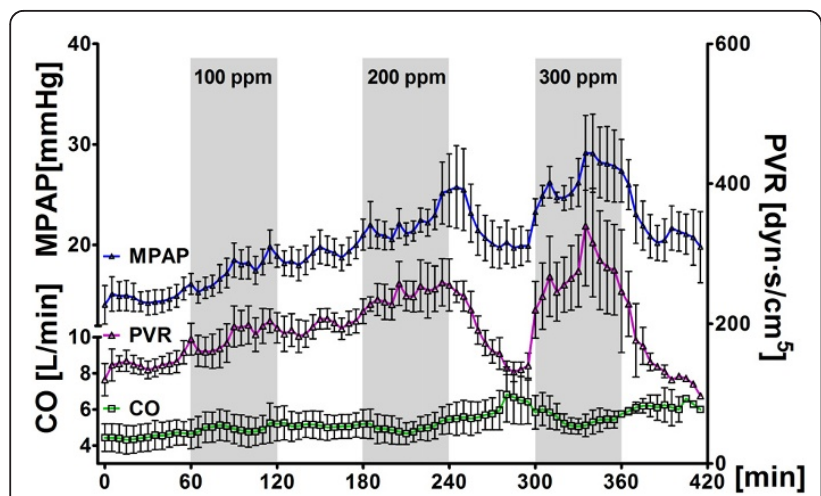

Figure 2 Pulmonary vascular hemodynamics. Pulmonary vascular hemodynamics in five sheep challenged with alternate exposure to hydrogen sulfide $\left(\mathrm{H}_{2} \mathrm{~S}\right)$ (gray bars) by ventilation of an

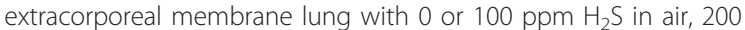
ppm $\mathrm{H}_{2} \mathrm{~S}$ in air and 300 ppm $\mathrm{H}_{2} \mathrm{~S}$ in air for 1-hour intervals each. Data are presented as means \pm standard error of the mean. MPAP, mean pulmonary artery pressure; $\mathrm{CO}$, cardiac output; PVR, pulmonary vascular resistance; ppm, parts per million.

systemic vascular resistance (SVR) from $1561 \pm 553$ dyn $\cdot \mathrm{s} / \mathrm{cm}^{5}$ to $870 \pm 138 \mathrm{dyn} \cdot \mathrm{s} / \mathrm{cm}^{5}$ (Table 1 ). We noted that MAP increased transiently during exposure to 100 and $200 \mathrm{ppm}_{2} \mathrm{~S}$ (Figure 1) and that this increase was rapidly reversed upon application of air without added $\mathrm{H}_{2} \mathrm{~S}$. Subsequently, exposure to $300 \mathrm{ppm}_{2} \mathrm{~S}$ induced a biphasic systemic pressor response characterized by increased MAP and SVR during the first 20 minutes of $\mathrm{H}_{2} \mathrm{~S}$ exposure followed by a rapid decrease of MAP and pronounced irreversible hypotension (Figure 1).

MPAP and pulmonary vascular resistance (PVR) increased in response to $\mathrm{H}_{2} \mathrm{~S}$ exposure, with the greatest increase ( $\triangle \mathrm{MPAP}$, approximately $10 \mathrm{mmHg}, \triangle \mathrm{PVR}$, $+51 \%$ ) observed in response to $300 \mathrm{ppm}_{2} \mathrm{~S}$ (Table 1).

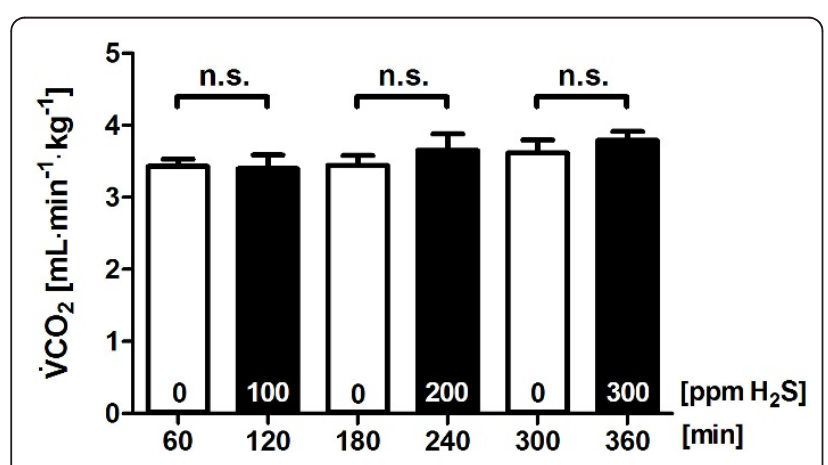

Figure 3 Carbon dioxide production during administration of hydrogen sulfide $\left(\mathrm{H}_{2} \mathrm{~S}\right)$. Total carbon dioxide production $\left(\dot{\mathrm{V}} \mathrm{CO}_{2}\right)$ in five sheep challenged with alternate exposure to $\mathrm{H}_{2} \mathrm{~S}$ by ventilation of an extracorporeal membrane lung with 0 or $100 \mathrm{ppm}$ $\mathrm{H}_{2} \mathrm{~S}$ in air, 200 ppm $\mathrm{H}_{2} \mathrm{~S}$ in air and $300 \mathrm{ppm} \mathrm{H}_{2} \mathrm{~S}$ in air for 1-hour intervals each. Values are derived from the last 10 minutes of each period of exposure to air or $\mathrm{H}_{2} \mathrm{~S}$ and are presented as means \pm standard error of the mean. ppm, parts per million; n.s. $=P>0.05$.

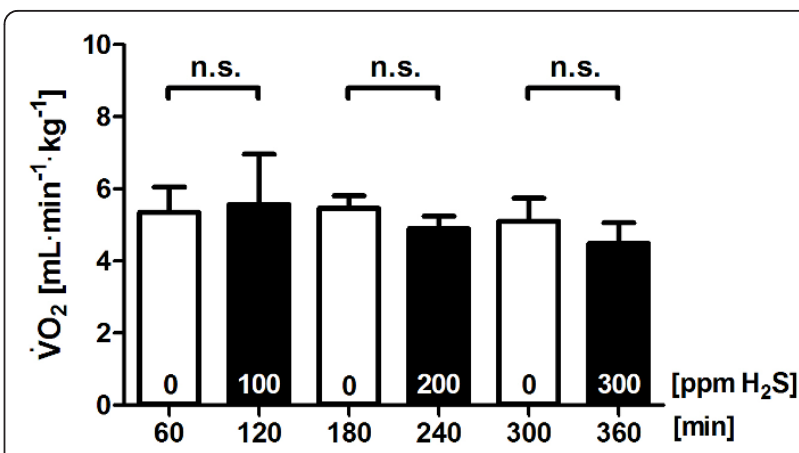

Figure 4 Oxygen consumption during administration of hydrogen sulfide $\left(\mathrm{H}_{2} \mathrm{~S}\right.$ ). Total carbon dioxide production $\left(\mathrm{V}_{2}\right.$ ) in five sheep challenged with alternate exposure to $\mathrm{H}_{2} \mathrm{~S}$ by ventilation of an extracorporeal membrane lung with 0 or 100 ppm $\mathrm{H}_{2} \mathrm{~S}$ in air, 200 ppm $\mathrm{H}_{2} \mathrm{~S}$ in air and 300 ppm $\mathrm{H}_{2} \mathrm{~S}$ in air for 1-hour intervals each. Values are derived from blood samples taken during the last 10 minutes of each period of exposure to air or $\mathrm{H}_{2} \mathrm{~S}$ and are presented as means \pm standard error of the mean. ppm, parts per million; n.s. $=P>0.05$

Time course analysis (Figure 2) suggested that PVR increased after exposure to 100,200 and $300 \mathrm{ppm} \mathrm{H}_{2} \mathrm{~S}$ in a reversible, dose-dependent manner. Heart rate and $\mathrm{CO}$ did not change in response to $\mathrm{H}_{2} \mathrm{~S}$ exposure.

\section{Pulmonary gas exchange and acid-base status}

Arterial $\mathrm{CO}_{2}$ tension levels were within physiological limits throughout the experiment and did not change in response to $\mathrm{H}_{2} \mathrm{~S}$. Mixed venous $\mathrm{CO}_{2}$ tension $\left(\mathrm{P}_{\mathrm{v}} \mathrm{CO}_{2}\right)$ ranged between 35 and $41 \mathrm{mmHg}$ and did not change in response to $\mathrm{H}_{2} \mathrm{~S}$. While arterial oxygenation $\left(\mathrm{P}_{\mathrm{a}} \mathrm{O}_{2}\right)$ was not significantly affected by 100 or $200 \mathrm{ppm} \mathrm{H}_{2} \mathrm{~S}, \mathrm{P}_{\mathrm{a}} \mathrm{O}_{2}$ decreased from $114 \pm 36$ to $83 \pm 23 \mathrm{mmHg}(P \leq 0.05)$ upon administration of $300 \mathrm{ppm} \mathrm{H}_{2} \mathrm{~S}$. Arterial oxygen tension did not recover during the subsequent interval of air exposure without $\mathrm{H}_{2} \mathrm{~S}$. Mixed venous $\mathrm{O}_{2}$ tension ranged between 50 and $56 \mathrm{mmHg}$, and there was no relevant change upon $\mathrm{H}_{2} \mathrm{~S}$ administration. While arterial $\mathrm{pH}\left(\mathrm{pH}_{\mathrm{a}}\right)$ was within physiological limits throughout the experiment, significant metabolic acidosis was observed during exposure to $300 \mathrm{ppm}_{2} \mathrm{~S}$, with concomitant changes in mixed venous $\mathrm{pH}$. Arterial hemoglobin concentrations were near $9 \mathrm{~g} / \mathrm{dl}$ throughout the experiment. Exposure to $200 \mathrm{ppm} \mathrm{H}_{2} \mathrm{~S}$ transiently increased hemoglobin concentrations by $2 \pm 0 \mathrm{~g} / \mathrm{dl}$ (Table 1 ).

\section{Total plasma sulfide concentrations}

Plasma sulfide concentrations were determined in duplicate from arterial and ECML-efferent blood. The baseline plasma concentration of sulfide was $1.9 \pm 0.3 \mu \mathrm{M}$, and this value was only slightly higher than the lower detection limit (approximately $1 \mu \mathrm{M}$ ) for this assay. Ventilation of ECML with air did not affect plasma 
Table 1 Hemodynamics and blood gas data ${ }^{a}$

\begin{tabular}{|c|c|c|c|c|c|c|}
\hline Parameter & $0 \mathrm{ppm}$ & 100 ppm & $0 \mathrm{ppm}$ & 200 ppm & $0 \mathrm{ppm}$ & 300 ppm \\
\hline \multicolumn{7}{|c|}{ Hemodynamics, means $\pm S D$} \\
\hline $\mathrm{HR}$, beats/min & $139 \pm 24$ & $148 \pm 29$ & $154 \pm 5$ & $172 \pm 28$ & $165 \pm 28$ & $150 \pm 31$ \\
\hline MAP, mmHg & $110 \pm 13$ & $117 \pm 14$ & $115 \pm 11$ & $128 \pm 16$ & $121 \pm 15$ & $66 \pm 11^{b}$ \\
\hline MPAP, mmHg & $15 \pm 3$ & $19 \pm 3^{*}$ & $19 \pm 3$ & $22 \pm 4$ & $20 \pm 4.0$ & $31 \pm 7^{b}$ \\
\hline $\mathrm{CO}, \mathrm{l} / \mathrm{min}$ & $4.6 \pm 1.4$ & $4.9 \pm 2.0$ & $5.1 \pm 1.5$ & $5.2 \pm 1.7$ & $5.8 \pm 2.3$ & $5.5 \pm 1.2$ \\
\hline CVP, mmHg & $9 \pm 2$ & $9 \pm 1.0$ & $10 \pm 1$ & $11 \pm 2$ & $11 \pm 1$ & $11 \pm 2$ \\
\hline PCWP, mmHg & $7 \pm 2$ & $7 \pm 2$ & $7 \pm 8$ & $8 \pm 2$ & $9 \pm 2$ & $10 \pm 2$ \\
\hline SVR, dyn.S/cm $\mathrm{cm}^{5}$ & $1,843 \pm 435$ & $1,948 \pm 525$ & $1,734 \pm 412$ & $2,009 \pm 703^{b}$ & $1,561 \pm 553$ & $870 \pm 138^{b}$ \\
\hline PVR, dyn:s/cm 5 & $145 \pm 32$ & $191 \pm 52^{\mathrm{b}}$ & $203 \pm 36$ & $255 \pm 70^{b}$ & $138 \pm 27$ & $279 \pm 138^{b}$ \\
\hline \multicolumn{7}{|c|}{$\begin{array}{l}\mathrm{Hb}, \mathrm{pH} \text {, blood gas tensions, and temperature, means } \pm \\
\mathrm{SD}\end{array}$} \\
\hline$H b_{a}, g / d l$ & $8.6 \pm 1.3$ & $9.0 \pm 1.3$ & $9.1 \pm 1.0$ & $11.1 \pm 1.4^{\mathrm{b}}$ & $9.5 \pm 0.6$ & $9.6 \pm 1.2$ \\
\hline $\mathrm{pH}_{\mathrm{a}}$ & $\begin{array}{l}7.401 \pm \\
0.072\end{array}$ & $\begin{array}{l}7.369 \pm \\
0.079\end{array}$ & $\begin{array}{c}7.375 \pm \\
0.051\end{array}$ & $\begin{array}{l}7.346 \pm \\
0.063\end{array}$ & $\begin{array}{l}7.312 \pm \\
0.089\end{array}$ & $\begin{array}{l}7.217 \pm \\
0.064^{\mathrm{b}}\end{array}$ \\
\hline $\mathrm{P}_{\mathrm{a}} \mathrm{O}_{2}, \mathrm{mmHg}$ & $161 \pm 28$ & $150 \pm 40$ & $150 \pm 37$ & $107 \pm 39$ & $114 \pm 36$ & $83 \pm 23^{b}$ \\
\hline $\mathrm{P}_{\mathrm{a}} \mathrm{CO}_{2}, \mathrm{mmHg}$ & $38 \pm 13$ & $38 \pm 11$ & $35 \pm 7$ & $34 \pm 5$ & $36 \pm 7.0$ & $38 \pm 4$ \\
\hline $\mathrm{pH}_{\mathrm{v}}$ & $\begin{array}{l}7.383 \pm \\
0.074\end{array}$ & $\begin{array}{l}7.360 \pm \\
0.080\end{array}$ & $\begin{array}{l}7.360 \pm \\
0.056\end{array}$ & $\begin{array}{l}7.346 \pm \\
0.066\end{array}$ & $\begin{array}{l}7.302 \pm \\
0.087\end{array}$ & $\begin{array}{l}7.210 \pm \\
0.068^{\mathrm{b}}\end{array}$ \\
\hline $\mathrm{P}_{\mathrm{v}} \mathrm{O}_{2}, \mathrm{mmHg}$ & $50 \pm 5$ & $52 \pm 6^{b}$ & $52 \pm 4$ & $54 \pm 4$ & $56 \pm 4$ & $52 \pm 7$ \\
\hline $\mathrm{P}_{\mathrm{v}} \mathrm{CO}_{2}, \mathrm{mmHg}$ & $41 \pm 14$ & $41 \pm 11$ & $38 \pm 8$ & $35 \pm 5$ & $38 \pm 6$ & $40 \pm 4$ \\
\hline Temperature, ${ }^{\circ} \mathrm{C}$ & $37.5 \pm 0.6$ & $37.5 \pm 0.4$ & $37.5 \pm 0.3$ & $37.3 \pm 0.4$ & $37.3 \pm 0.4$ & $37.1 \pm 0.5$ \\
\hline
\end{tabular}

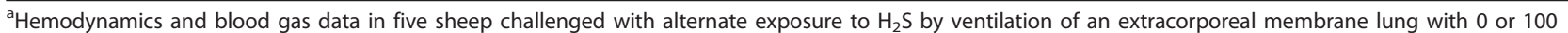
ppm $\mathrm{H}_{2} \mathrm{~S}, 200$ ppm $\mathrm{H}_{2} \mathrm{~S}$ or 300 ppm $\mathrm{H}_{2} \mathrm{~S}$ in air for 1-hour intervals each. ppm, parts per million; HR, heart rate; MAP, mean arterial pressure; MPAP, mean pulmonary artery pressure; $\mathrm{CO}$, cardiac output; CVP, central venous pressure; PCWP, pulmonary capillary wedge pressure; SVR, systemic vascular resistance; PVR, pulmonary vascular resistance; $\mathrm{Hb}_{\mathrm{a}}$, arterial hemoglobin concentration; $\mathrm{pH}_{\mathrm{a}}$, arterial $\mathrm{pH} ; \mathrm{P}_{\mathrm{a}} \mathrm{O}_{2}$, arterial oxygen tension; $\mathrm{P}_{\mathrm{a}} \mathrm{CO}_{2}$, arterial carbon dioxide tension; $\mathrm{pH}$, mixed venous $\mathrm{pH} ; \mathrm{P}_{\mathrm{v}} \mathrm{O}_{2}$, mixed venous oxygen tension; $\mathrm{P}_{\mathrm{v}} \mathrm{CO}_{2}$, mixed venous carbon dioxide tension. All values are means $\pm \mathrm{SD}$ and reflect the last 10 minutes of each 1-hour period. $n=5$. Values during $\mathrm{H}_{2} \mathrm{~S}$ exposure were compared using Student's $t$-test or the Wilcoxon signed-rank test with the preceding 0 ppm baseline period, that is, first vs. second hour, third vs. fourth hour and fifth vs. sixth hour; ${ }^{\mathrm{b}} P \leq 0.05$.

sulfide concentrations in the efferent blood of the ECML. In ECML-efferent blood, plasma sulfide concentration increased to $7 \pm 6,27 \pm 6$ and $62 \pm 12 \mu \mathrm{M} / 1$ during ECML ventilation with 100, 200 and $300 \mathrm{ppm}$ $\mathrm{H}_{2} \mathrm{~S}$, respectively. However, no sulfide was detected in plasma samples of blood collected from the femoral

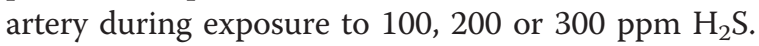

\section{Discussion}

The results of the present study reveal that ventilating an ECML with up to $300 \mathrm{ppm} \mathrm{H}_{2} \mathrm{~S}$ in venoarterial cardiac bypass circulation does not reduce whole body $\mathrm{CO}_{2}$ production or $\mathrm{O}_{2}$ consumption in anesthetized sheep. In addition, we have demonstrated that administration of $300 \mathrm{ppm} \mathrm{H}_{2} \mathrm{~S}$ via ECML ventilation causes significant adverse effects, including pulmonary vasoconstriction, systemic vasodilation and hypoxemia. The current results do not support the hypothesis that high concentrations of $\mathrm{H}_{2} \mathrm{~S}$ delivered via an ECML can reduce the metabolic rate in large mammals at rest.

In an attempt to bypass the direct pulmonary toxicity of inhaled $\mathrm{H}_{2} \mathrm{~S}$, we used an ECML to directly diffuse high concentrations of $\mathrm{H}_{2} \mathrm{~S}$ gas into the blood. The absence of $\mathrm{H}_{2} \mathrm{~S}$ (lower limit of detection $1 \mathrm{ppm}$ ) in the gas outlet of the artificial lung during ventilation with up to $300 \mathrm{ppm}$ $\mathrm{H}_{2} \mathrm{~S}$ indicates that $\mathrm{H}_{2} \mathrm{~S}$ is highly diffusible into blood through the membrane and that a single passage is sufficient for complete uptake of the gas. Thus, assuming complete uptake of $\mathrm{H}_{2} \mathrm{~S}$ during ventilation of the ECML at a gas flow of $5 \mathrm{l} / \mathrm{min}$ with $300 \mathrm{ppm}_{2} \mathrm{~S}$ (at standard conditions for temperature and pressure), a total amount of 1.5 $\mathrm{ml}$ of $\mathrm{H}_{2} \mathrm{~S}$ (that is, approximately $67 \mu \mathrm{M}$ ) are administered via the membrane every minute. This sums to about 134 $\mu \mathrm{M} \mathrm{H}_{2} \mathrm{~S} / \mathrm{kg}$ per hour delivered to a 30-kg sheep in the current study. In contrast, the total amount of $\mathrm{H}_{2} \mathrm{~S}$ administered in previous studies in sheep [15] and pigs [16] were approximately $13 \mu \mathrm{M} / \mathrm{kg} / \mathrm{h}$ and approximately $42 \mu \mathrm{M} / \mathrm{kg} /$ h, respectively, assuming complete uptake of $\mathrm{H}_{2} \mathrm{~S}$ from the alveolar space and an alveolar ventilation of $6 \mathrm{l} / \mathrm{min}$ in a 74- $\mathrm{kg}$ sheep, and $1.2 \mathrm{l} / \mathrm{min}$ in a $6-\mathrm{kg}$ pig. Therefore, the systemic dose of $\mathrm{H}_{2} \mathrm{~S}$ supplied in the present study was about three times greater than that applied in pigs and 10 times greater than the dose applied in sheep. If any of the alveolar $\mathrm{H}_{2} \mathrm{~S}$ were exhaled, the ratio of the uptake via the membrane artificial lung in the present study and the uptake via the natural lungs in previous reports would be even greater. Nonetheless, our measurements suggest that administration of $\mathrm{H}_{2} \mathrm{~S}$ up to $134 \mu \mathrm{M} / \mathrm{kg} / \mathrm{h}$ does not reduce $\dot{\mathrm{V}} \mathrm{CO}_{2}$ or $\dot{\mathrm{VO}}_{2}$ in sheep. 
While $\mathrm{H}_{2} \mathrm{~S}$ did not reduce $\dot{\mathrm{V}} \mathrm{CO}_{2}$ or $\dot{\mathrm{V}} \mathrm{O}_{2}$ in sheep in the present study, Simon et al. [21] reported that continuous iv infusion of $\mathrm{Na}_{2} \mathrm{~S}$ for 8 hours decreased the core body temperature and $\dot{\mathrm{V}} \mathrm{CO}_{2}$ and $\dot{\mathrm{VO}}_{2}$ levels in pigs, suggesting that it is possible to reduce metabolic rates in large mammals using a sulfide-based approach. However, it is important to note that hypothermia itself reduces the metabolic rate $\left(Q_{10}\right.$ effect). Therefore, in the current study, body temperature was kept at $37^{\circ} \mathrm{C}$ throughout the experiment to exclude any effects of hypothermia on metabolism. Whether systemic administration of $\mathrm{Na}_{2} \mathrm{~S}$ reduces metabolic rates in large mammals when normothermia is maintained remains to be determined.

While our findings support the inability of $\mathrm{H}_{2} \mathrm{~S}$ to reduce metabolism in large mammals, these results differ from observations in mice in which $\mathrm{H}_{2} \mathrm{~S}$ inhalation markedly reduced metabolism $[9,10,22]$. Hydrogen sulfide may be one, but not the only, trigger for murine metabolic depression. Indeed, hypoxia, anemia and exposure to carbon monoxide have been reported to reduce aerobic metabolism in mice [23-25], but not in large mammals [26-28]. Of note is that mice are known to have a much higher specific metabolic rate (approximately $168 \mathrm{kcal} \mathrm{kg}^{-1} \cdot \mathrm{d}^{-1}$ in a $30-\mathrm{g}$ mouse) than sheep (approximately $30 \mathrm{kcal} \mathrm{kg}^{-1} \cdot \mathrm{d}^{-1}$ in a 30-kg sheep) [29]. In a previous study, we reported that $\mathrm{H}_{2} \mathrm{~S}$ inhalation reduced metabolism in awake, spontaneously breathing mice by about $40 \%$ during normothermia, resulting in a specific metabolic rate of no more than approximately $100 \mathrm{kcal} \cdot \mathrm{kg}^{-1} \cdot \mathrm{d}^{-1}$ [9]. In contrast, it has been reported that $\mathrm{H}_{2} \mathrm{~S}$ inhalation at $100 \mathrm{ppm}$ failed to reduce $\mathrm{CO}_{2}$ production in normothermic mice that were anesthetized and mechanically ventilated [30]. Interestingly, in anesthetized mice studied by Baumgart et al. [30], the baseline $\mathrm{CO}_{2}$ production rate before $\mathrm{H}_{2} \mathrm{~S}$ inhalation was approximately $50 \%$ less than that in awake mice studied by Volpato et al. [9] in our laboratory. It is tempting to speculate that the ability of $\mathrm{H}_{2} \mathrm{~S}$ to reduce metabolism depends on the specific metabolic rate of animals. $\mathrm{H}_{2} \mathrm{~S}$ may reduce metabolism when the baseline rate of metabolism is high (for example, in awake mice), but not when the metabolic rate is already depressed (for example, in anesthetized mice or sheep).

Along these lines, it may be possible to reduce the metabolic rate in larger mammals using $\mathrm{H}_{2} \mathrm{~S}$ when metabolism is increased. It has been reported that inhalation of $10 \mathrm{ppm} \mathrm{H}_{2} \mathrm{~S}$ reduced oxygen consumption in exercising healthy volunteers, presumably due to inhibition of aerobiosis in exercising muscle [31]. Inhibitory effects of $\mathrm{H}_{2} \mathrm{~S}$ in the presence of increased metabolism in larger mammals warrants further study.
Our results show that administration of $\mathrm{H}_{2} \mathrm{~S}$ via a cardiopulmonary bypass circulation can cause significant dosedependent pulmonary vasoconstriction. These observations are consistent with the pulmonary vasoconstrictor effects of $\mathrm{H}_{2} \mathrm{~S}$ in mammalian pulmonary vessels reported by Olson et al. [32]. Although a potential role of $\mathrm{H}_{2} \mathrm{~S}$ in hypoxia sensing (hence hypoxic pulmonary vasoconstriction) has been suggested [33], the mechanisms responsible for the pulmonary vasoconstrictor effects of $\mathrm{H}_{2} \mathrm{~S}$ remain to be further elucidated.

Administration of $\mathrm{H}_{2} \mathrm{~S}$ also tended to increase systemic vascular resistance, but resulted in systemic vasodilation after 30 minutes of ECML ventilation with 300 ppm $\mathrm{H}_{2} \mathrm{~S}$. This is consistent with previous reports demonstrating that $\mathrm{H}_{2} \mathrm{~S}$ can produce both vasoconstriction and vasorelaxation in isolated rat aortic ring segments in an $\mathrm{O}_{2}$ concentration-dependent manner. Koenitzer et al. [34] reported that $\mathrm{H}_{2} \mathrm{~S}$ (5 to $80 \mu \mathrm{M}$ $\mathrm{Na}_{2} \mathrm{~S}$ solution) causes vasorelaxation at $\mathrm{O}_{2}$ concentrations reflecting the physiological oxygen tension in the peripheral vasculature $\left(\mathrm{O}_{2}\right.$ concentration, $\left.40 \mu \mathrm{M}\right)$. In contrast, at high $\mathrm{O}_{2}$ concentrations $\left(\mathrm{O}_{2}, 200 \mu \mathrm{M}\right)$ under which $\mathrm{H}_{2} \mathrm{~S}$ is rapidly oxidized to sulfite, sulfate or thiosulfate, the administration of 5 to $100 \mu \mathrm{M} \mathrm{Na} \mathrm{Na}_{2} \mathrm{~S}$ causes rat aortic vasoconstriction, and more than $200 \mu \mathrm{M} \mathrm{Na} \mathrm{Na}_{2} \mathrm{~S}$ are required to cause vasorelaxation [34]. Along these lines, the high oxygen tension observed in sheep on ECML when ventilated with 100 and $200 \mathrm{ppm}$ of $\mathrm{H}_{2} \mathrm{~S}$ may have contributed to the systemic vasoconstrictor effects of $\mathrm{H}_{2} \mathrm{~S}$ in the present study, whereas vasodilation was only observed at the highest $\mathrm{H}_{2} \mathrm{~S}$ concentration (300 ppm). In addition, the $\mathrm{O}_{2}$ dependency of $\mathrm{H}_{2} \mathrm{~S}$ mediated vasoconstriction may also explain why $\mathrm{H}_{2} \mathrm{~S}$ caused vasoconstriction in the pulmonary vasculature, where $\mathrm{O}_{2}$ availability is consistently high.

While the toxicity of inhaling high levels of $\mathrm{H}_{2} \mathrm{~S}$ is well documented, the reported toxicity of $\mathrm{H}_{2} \mathrm{~S}$ concentrations up to $500 \mathrm{ppm}$ is almost exclusively limited to mucosal membranes and the central nervous system [35-37]. However, the cardiovascular toxicity of high levels of inhaled $\mathrm{H}_{2} \mathrm{~S}$ has not been reported. The observed pulmonary hypertension and apparent changes in systemic vascular tone in the current study may therefore represent previously unrecognized toxic effects of high levels of $\mathrm{H}_{2} \mathrm{~S}$ in the circulation.

Despite the availability of various methods used to quantify sulfide in biological fluids, it remains challenging to measure circulating plasma concentrations of $\mathrm{H}_{2} \mathrm{~S}$ [38]. The methylene blue formation method employed here measures "labile" total sulfide liberated from sulfur compounds, but not free $\mathrm{H}_{2} \mathrm{~S}$ in blood and tissue. In the current study, considerable sulfide concentrations were detected in plasma obtained from blood 
efferent from the ECML, but not in the blood samples from the femoral artery (sampled less than approximately 10 seconds after the blood left the ECML). These observations suggest a rapid uptake of $\mathrm{H}_{2} \mathrm{~S}$ into a variety of sulfide pools once $\mathrm{H}_{2} \mathrm{~S}$ has entered the blood stream. Of note is that the measured plasma sulfide level of $62 \mu \mathrm{M} / \mathrm{l}$ in the ECML efferent blood diffused with $300 \mathrm{ppm} \mathrm{H}_{2} \mathrm{~S}$ was only about $3 \%$ of the expected sulfide level of approximately $2,000 \mu \mathrm{M} / \mathrm{l}$ assuming a blood volume of $70 \mathrm{ml} / \mathrm{kg}$. These results are consistent with a recent report that circulating free sulfide levels are almost undetectably low at baseline and that exogenous sulfide is also rapidly removed from the circulating plasma [39]. Nonetheless, the pronounced vasoreactivity induced by $\mathrm{H}_{2} \mathrm{~S}$ administration observed in the current study suggests that $\mathrm{H}_{2} \mathrm{~S}$ (and/or its active metabolites) is transported to the periphery and exerts biological effects. The fate of exogenously administered $\mathrm{H}_{2} \mathrm{~S}$ remains to be determined in future studies using more sensitive methods.

Although the results of the current study do not suggest that $\mathrm{H}_{2} \mathrm{~S}$ can be used to reduce metabolic rate in larger mammals, these results do not refute the potential organ protective effects of $\mathrm{H}_{2} \mathrm{~S}$ reported elsewhere. The dose of $134 \mu \mathrm{M} / \mathrm{kg} / \mathrm{h}$ that was applied here is almost 20 times higher than the effective dose of $\mathrm{Na}_{2} \mathrm{~S}$ reported to improve survival in mice after cardiac arrest $(0.55 \mu \mathrm{g} / \mathrm{g}$, that is, approximately $7 \mu \mathrm{M} / \mathrm{kg}$ ) [12]. Studies by others have also shown that administration of $\mathrm{H}_{2} \mathrm{~S}$ donors in a similarly low dose range were able to protect organs from ischemic insults in rodents and pigs without reducing metabolic rate or body temperature $[14,40]$. Taken together, it is conceivable that organ-protective effects and metabolic effects of $\mathrm{H}_{2} \mathrm{~S}$ may be mediated via two different mechanisms and/or at different concentrations.

\section{Limitations}

Measuring oxygen consumption is a valuable tool to assess metabolic rate. However, quantification of oxygen consumption in the setting of ECML requires serial simultaneous determinations of oxygen content in arterial and mixed venous blood as well as blood afferent and efferent to the ECML [41]. Small measuring inaccuracies in the parameters needed to calculate oxygen content (hemoglobin, oxygen saturation and tension) result in an exponential increase in the overall inaccuracy of the calculated $\mathrm{V}_{2}$ value. In contrast, measuring $\mathrm{CO}_{2}$ production requires only $\mathrm{CO}_{2}$ quantification in the exhaled gas of both the natural and the artificial lung because virtually no $\mathrm{CO}_{2}$ is present in the inhaled gas mixture, which is a major advantage to simplifying the setup and avoiding exponential error. Therefore, $\dot{\mathrm{COO}}_{2}$ may be the more reliable index for estimating the metabolic rate in this study.
The present study was designed to detect a reduction in metabolic rate of about $30 \%$ in sheep. On the basis of the variance of metabolic rates determined in pilot experiments in sheep, a sample size of 12 sheep was calculated to find a $30 \%$ reduction in metabolic rate $(80 \%$ power and $5 \%$ probability of error). An interim analysis of this study $(n=5)$ did not substantiate a significant change or trend in $\dot{\mathrm{V}} \mathrm{CO}_{2}$ (Figure 3 ) and precluded additional experiments.

\section{Conclusions}

The results of the present study demonstrate that venti-

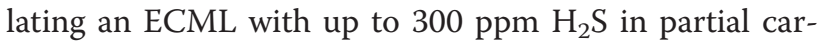
diopulmonary bypass circulation does not reduce $\mathrm{CO}_{2}$ production or $\mathrm{O}_{2}$ consumption in anesthetized sheep. Our results show that diffusion of up to $300 \mathrm{ppm} \mathrm{H}_{2} \mathrm{~S}$ into blood via a membrane lung can cause dose-dependent pulmonary vasoconstriction, hypoxemia and catastrophic systemic vasodilation. These observations do not support the hypothesis that administration of a high concentration of $\mathrm{H}_{2} \mathrm{~S}$ reduces metabolism in anesthetized large mammals. Whether the administration of $\mathrm{H}_{2} \mathrm{~S}$ inhibits metabolism in large mammals when metabolic rate is increased (for example, systemic inflammation or exercise) remains to be determined.

\section{Key messages}

- High concentrations of $\mathrm{H}_{2} \mathrm{~S}$ administered via ECML ventilation do not alter $\mathrm{CO}_{2}$ production in sheep on partial cardiopulmonary bypass perfusion.

- In this setting, $\mathrm{H}_{2} \mathrm{~S}$ poses the risk of pulmonary vasoconstriction, hypoxemia and systemic vasodilation.

- Therefore, administration of high concentrations of $\mathrm{H}_{2} \mathrm{~S}$ via membrane lung may not be useful for reducing oxidative metabolism in large mammals.

\section{Abbreviations}

$\mathrm{C}_{\mathrm{a}} \mathrm{O}_{2}$ : arterial oxygen content; $\mathrm{C}_{\mathrm{e}} \mathrm{O}_{2}$ : efferent oxygen content; $\mathrm{CO}$ : cardiac output; $\mathrm{CO}_{2}$ : carbon dioxide; $\mathrm{C}_{\mathrm{v}} \mathrm{O}_{2}$ : mixed venous oxygen content; $\mathrm{CVP}$ : central venous pressure; ECML: extracorporeal membrane lung; $\mathrm{FeCl}_{3}$ : iron(III) chloride; $\mathrm{F}_{\mathrm{E}} \mathrm{CO}_{2}$ : mean fraction of $\mathrm{CO}_{2}$ in expired air; $\mathrm{F}_{i} \mathrm{O}_{2}$ : fraction of inspired oxygen; $\mathrm{Hb}$ : hemoglobin concentration; $\mathrm{HCl}$ : hydrogen chloride; $\mathrm{HR}$ : heart rate; $\mathrm{H}_{2} \mathrm{~S}$ : hydrogen sulfide; iv: intravenously; MAP: mean arterial pressure; mmHg: millimeters of mercury; MPAP: mean pulmonary artery pressure; $\mathrm{NaHS}$ : sodium hydrosulfide; $\mathrm{Na}_{2} \mathrm{~S}$ : sodium sulfide; $\mathrm{O}_{2}$ : oxygen; $\mathrm{P}_{2} \mathrm{CO}_{2}, \mathrm{PCWP}$ : pulmonary capillary wedge pressure; arterial carbon dioxide tension; $\mathrm{pH}_{\mathrm{a}}$ arterial $\mathrm{pH}$; ppm: parts per million; $\mathrm{pO}_{2}$ : oxygen tension; $\mathrm{VCO}_{2}$ : carbon dioxide production; $\dot{V}_{2}$ : oxygen consumption; $\dot{V}_{\mathrm{E}}$ : expiratory minute volume; $\dot{V}_{\mathrm{L}} \mathrm{CO}_{2}$ : amount of $\mathrm{CO}_{2}$ exhaled from the lungs per unit of time; $\dot{\mathrm{V}}_{\mathrm{M}} \mathrm{CO}_{2}$ : amount of $\mathrm{CO}_{2}$ removed from the circulation via membrane oxygenator per unit of time.

\section{Acknowledgements}

This work was supported by fellowship grants from the German Research Foundation (Deutsche Forschungsgemeinschaft) to MD (DE 1685/1-1) and RCF (FR 2555/3-1), by laboratory funds of WMZ and National Institutes of Health grant R01 HL101930 to FI. CA was supported by the Arthur Sachs Scholarship Fund. We are indebted to Dr. Kenneth D. Bloch from the 
Department of Anesthesia, Critical Care and Pain Medicine, Massachusetts General Hospital, for advice and assistance in the design of the study and in the editing of the manuscript.

\section{Author details}

${ }^{1}$ Anesthesia Center for Critical Care Research, Department of Anesthesia, Critical Care and Pain Medicine, Massachusetts General Hospital and Harvard Medical School, 55 Fruit Street, Boston, MA 02114, USA. ²Department of Anesthesia, Medical Faculty, RWTH Aachen University, Pauwelsstrasse 30, D52074 Aachen, Germany.

\section{Authors' contributions}

MD and RCF performed the experiments and data analysis, contributed to the design and interpretation of the study and wrote the manuscript. KK performed plasma $\mathrm{H}_{2} \mathrm{~S}$ measurements and helped perform the experiments. $M B$, EC and CA contributed to the study setup. WMZ and FI contributed to the conceptual design of the study, to the interpretation of data, and to manuscript writing and editing. WMZ and FI contributed equally to this study. All authors have read and approved the final manuscript.

\section{Competing interests}

The authors declare that they have no competing interests.

Received: 22 September 2010 Revised: 15 December 2010

Accepted: 7 February 2011 Published: 7 February 2011

\section{References}

1. Arrich J, Holzer M, Herkner H, Mullner M: Hypothermia for neuroprotection in adults after cardiopulmonary resuscitation. Cochrane Database Syst Rev 2009, CD004128.

2. Fukudome EY, Alam HB: Hypothermia in multisystem trauma. Crit Care Med 2009, 37:S265-272

3. Grigore AM, Murray CF, Ramakrishna H, Djaiani G: A core review of temperature regimens and neuroprotection during cardiopulmonary bypass: does rewarming rate matter? Anesth Analg 2009, 109:1741-1751.

4. Polderman $\mathrm{KH}$ : Mechanisms of action, physiological effects, and complications of hypothermia. Crit Care Med 2009, 37:5186-202.

5. Mild therapeutic hypothermia to improve the neurologic outcome after cardiac arrest. N Engl J Med 2002, 346:549-556.

6. Fries $M$, Stoppe $C$, Brücken D, Rossaint R, Kuhlen R: Influence of mild therapeutic hypothermia on the inflammatory response after successful resuscitation from cardiac arrest. J Crit Care 2009, 24:453-457.

7. Dorman DC, Moulin FJ, McManus BE, Mahle KC, James RA, Struve MF: Cytochrome oxidase inhibition induced by acute hydrogen sulfide inhalation: correlation with tissue sulfide concentrations in the rat brain, liver, lung, and nasal epithelium. Toxicol Sci 2002, 65:18-25.

8. Struve MF, Brisbois JN, James RA, Marshall MW, Dorman DC: Neurotoxicological effects associated with short-term exposure of Sprague-Dawley rats to hydrogen sulfide. Neurotoxicology 2001, 22:375-385.

9. Volpato GP, Searles R, Yu B, Scherrer-Crosbie M, Bloch KD, Ichinose F Zapol WM: Inhaled hydrogen sulfide: a rapidly reversible inhibitor of cardiac and metabolic function in the mouse. Anesthesiology 2008 108:659-668

10. Blackstone $E$, Roth $M B$ : Suspended animation-like state protects mice from lethal hypoxia. Shock 2007, 27:370-372

11. Morrison ML, Blackwood JE, Lockett SL, Iwata A, Winn RK, Roth MB: Surviving blood loss using hydrogen sulfide. J Trauma 2008, 65:183-188.

12. Minamishima S, Bougaki M, Sips PY, Yu JD, Minamishima YA, Elrod JW, Lefer DJ, Bloch KD, Ichinose F: Hydrogen sulfide improves survival after cardiac arrest and cardiopulmonary resuscitation via a nitric oxide synthase 3-dependent mechanism in mice. Circulation 2009, 120:888-896.

13. Elrod JW, Calvert JW, Morrison J, Doeller JE, Kraus DW, Tao L, Jiao X Scalia R, Kiss L, Szabo C, Kimura H, Chow CW, Lefer DJ: Hydrogen sulfide attenuates myocardial ischemia-reperfusion injury by preservation of mitochondrial function. Proc Natl Acad Sci USA 2007, 104:15560-15565.

14. Sodha NR, Clements RT, Feng J, Liu Y, Bianchi C, Horvath EM, Szabo C, Sellke FW: The effects of therapeutic sulfide on myocardial apoptosis in response to ischemia-reperfusion injury. Eur J Cardiothorac Surg 2008, 33:906-913.

15. Haouzi P, Notet V, Chenuel B, Chalon B, Sponne I, Ogier V, Bihain B: H2S induced hypometabolism in mice is missing in sedated sheep. Respir Physiol Neurobiol 2008, 160:109-115.

16. Li J, Zhang G, Cai S, Redington AN: Effect of inhaled hydrogen sulfide on metabolic responses in anesthetized, paralyzed, and mechanically ventilated piglets. Pediatr Crit Care Med 2008, 9:110-112.

17. Beauchamp RO Jr, Bus JS, Popp JA, Boreiko CJ, Andjelkovich DA: A critical review of the literature on hydrogen sulfide toxicity. Crit Rev Toxicol 1984, 13:25-97.

18. Reiffenstein RJ, Hulbert WC, Roth SH: Toxicology of hydrogen sulfide. Annu Rev Pharmacol Toxicol 1992, 32:109-134.

19. Siegel LM: A Direct Microdetermination for Sulfide. Anal Biochem 1965 11:126-132.

20. Dupont WD, Plummer WD Jr: Power and sample size calculations for studies involving linear regression. Control Clin Trials 1998, 19:589-601.

21. Simon F, Giudici R, Duy CN, Schelzig H, Oter S, Groger M, Wachter U, Vogt J, Speit G, Szabo C, Radermacher P, Calzia E: Hemodynamic and metabolic effects of hydrogen sulfide during porcine ischemia/ reperfusion injury. Shock 2008, 30:359-364.

22. Blackstone $\mathrm{E}$, Morrison $\mathrm{M}$, Roth $\mathrm{MB}$ : $\mathrm{H} 2 \mathrm{~S}$ induces a suspended animationlike state in mice. Science 2005, 308:518.

23. Gautier $\mathrm{H}$, Bonora M: Ventilatory and metabolic responses to cold and CO-induced hypoxia in awake rats. Respir Physiol 1994, 97:79-91.

24. Matsuoka M, Igisu H, Tanaka I, Hori H, Koga M: Effects of hypo- and hyperglycemia on brain energy metabolites in mice exposed to carbon monoxide. Toxicol Lett 1994, 73:135-143.

25. Singer D: Metabolic adaptation to hypoxia: cost and benefit of being small. Respir Physiol Neurobiol 2004, 141:215-228.

26. Forster HV, Bisgard GE, Klein JP: Effect of peripheral chemoreceptor denervation on acclimatization of goats during hypoxia. J Appl Physio 1981, 50:392-398.

27. Frappell P, Lanthier C, Baudinette RV, Mortola JP: Metabolism and ventilation in acute hypoxia: a comparative analysis in small mammalian species. Am J Physiol 1992, 262:R1040-1046.

28. Korducki MJ, Forster HV, Lowry TF, Forster MM: Effect of hypoxia on metabolic rate in awake ponies. J Appl Physiol 1994, 76:2380-2385.

29. Schmidt-Nielsen K: Scaling: Why is Animal Size so Important? Cambridge, UK: Cambridge University Press; 1984

30. Baumgart K, Wagner F, Groger M, Weber S, Barth E, Vogt JA, Wachter U, Huber-Lang M, Knoferl MW, Albuszies G, Georgieff M, Asfar P, Szabó C, Calzia E, Radermacher P, Simkova V: Cardiac and metabolic effects of hypothermia and inhaled hydrogen sulfide in anesthetized and ventilated mice. Crit Care Med 2010, 38:588-595.

31. Bhambhani Y, Burnham R, Snydmiller G, MacLean I: Effects of 10-ppm hydrogen sulfide inhalation in exercising men and women. Cardiovascular, metabolic, and biochemical responses. J Occup Environ Med 1997, 39:122-129.

32. Olson KR, Dombkowski RA, Russell MJ, Doellman MM, Head SK, Whitfield NL, Madden JA: Hydrogen sulfide as an oxygen sensor/ transducer in vertebrate hypoxic vasoconstriction and hypoxic vasodilation. J Exp Biol 2006, 209:4011-4023.

33. Olson KR, Whitfield NL, Bearden SE, St Leger J, Nilson E, Gao Y, Madden JA: Hypoxic pulmonary vasodilation: a paradigm shift with a hydrogen sulfide mechanism. Am J Physiol Regul Integr Comp Physiol 2010, 298:R51-60.

34. Koenitzer JR, Isbell TS, Patel HD, Benavides GA, Dickinson DA, Patel RP, Darley-Usmar VM, Lancaster JR Jr, Doeller JE, Kraus DW: Hydrogen sulfide mediates vasoactivity in an O2-dependent manner. Am J Physiol Heart Circ Physiol 2007, 292:H1953-1960.

35. OSHA/EPA Occupational Chemical Database. [http://www.osha.gov/web/ dep/chemicaldata/].

36. WHO International Programme on Chemical Safety. [http://www.who.int/ ipcs/en/].

37. Guidotti TL: Hydrogen Sulfide: Advances in Understanding Human Toxicity. Int J Toxicol 2010.

38. Kajimura M, Fukuda R, Bateman RM, Yamamoto T, Suematsu M: Interactions of multiple gas-transducing systems: hallmarks and 
uncertainties of CO, NO, and H2S gas biology. Antioxid Redox Signal 2010, 13:157-192.

39. Whitfield NL, Kreimier EL, Verdial FC, Skovgaard N, Olson KR: Reappraisal of $\mathrm{H} 2 \mathrm{~S} /$ sulfide concentration in vertebrate blood and its potential significance in ischemic preconditioning and vascular signaling. Am $J$ Physiol Regul Integr Comp Physiol 2008, 294:R1930-1937.

40. Henderson PW, Weinstein AL, Sung J, Singh SP, Nagineni V, Spector JA Hydrogen sulfide attenuates ischemia-reperfusion injury in in vitro and in vivo models of intestine free tissue transfer. Plast Reconstr Surg 2010, 125:1670-1678.

41. Snider M, Zapol W: Assessment of pulmonary oxygenation during venoarterial bypass with aortic root return. In Artificial Lungs and Acute Respiratory Failure: Theory and Practice. Edited by: Zapol W, Qvist J. Washington, D.C.: Hemisphere Publishing Corporation; 1976:257-273.

doi:10.1186/cc10016

Cite this article as: Derwall et al:: Administration of hydrogen sulfide via extracorporeal membrane lung ventilation in sheep with partial cardiopulmonary bypass perfusion: a proof of concept study on metabolic and vasomotor effects. Critical Care 2011 15:R51.

\section{Submit your next manuscript to BioMed Central} and take full advantage of:

- Convenient online submission

- Thorough peer review

- No space constraints or color figure charges

- Immediate publication on acceptance

- Inclusion in PubMed, CAS, Scopus and Google Scholar

- Research which is freely available for redistribution

Submit your manuscript at www.biomedcentral.com/submit 